\title{
Remembering pre-independence childhoods in South India: interrogating autobiographies and identities
}

\author{
Catriona Ellis \\ University of Strathclyde
}

catriona.ellis@strath.ac.uk

\begin{abstract}
This article discusses the potential of autobiography for understanding histories of childhood, the effects of late-colonial social policy and the experience of change in India in the decades immediately preceding independence in 1947. This was an era characterised by both increased state intervention in the lives of poor Indian children and the growing influence of universalising notions about modern childhood. Based on a detailed study of 55 autobiographies produced by those born between 1910 and 1940, the article analyses the ways in which childhood was imagined, defined and discussed by South Indians through memories that coalesce around the themes of innocence, play, education, work, family and social identity. It demonstrates that these narrations of memory also convey aspirations for contemporary Indian children through comparative reference to the binary of 'today' and 'those days'. The article reveals the complexity of ideas and experiences at a local level which, despite the commonality of age, were refracted through the distinctions of gender, religion, race and class.
\end{abstract}

\section{KEYWORDS}

Childhood, India, autobiography, education, play, family. 
Former missile scientist and widely recognised 'People's President' of India A.P.J. Abdul Kalam recalled his childhood in the 1930s through 'beautiful memories of days of innocence and mischief and learning'. ${ }^{1}$ Autobiographies, as 'straddling the elusive divide between personal narrative and objective truth', provide both an insight on the lived experiences of children (through the act of remembering past time) and on the adult construction of normative discourses about childhood (that are shaped by the concerns of the present). ${ }^{2}$ This article analyses autobiographies produced by those who were children in the 1920s and 1930s to highlight the complex, uneven and gradual ways in which ideas about childhood were changing in South India in the decades before independence in 1947. As well as discussing the concepts of innocence, play and education that Kalam highlights as the defining contours of 'childhood', it also demonstrates the continued importance of family relationships, the workplace and the politics of social identity in shaping children's lives.

Historians have long argued that the ways in which childhood is understood and constructed vary according to time and space; and thus the way childhood is imagined in India reflects the particular economic and social structures of the subcontinent and the historical experience of colonialism and post-independence statehood. ${ }^{3}$ Yet this argument sits uneasily with contemporary popular ideas that inform state and humanitarian intervention in India - in which the universalising claims of the category of age, associated with vulnerability and innocence and the conviction that 'mankind owes to the child the best it has to give'- supersede all other claims to identity, even when the cultural specificities of children's experiences are acknowledged. ${ }^{4}$ Conversely, the claim to a distinctive 'Indian childhood' has been used to reify 'Indian culture', essentialising and homogenising it as static in unthinkingly orientalist ways. ${ }^{5}$ Sociologist Adrian James resolves this by advocating a model which both reflects the 'commonalities' or 'analytical and conceptual strands' which underpin all understandings of childhood but also reveals the 'diversities of childhood' and which reflect historical, geographical, socio-economic and cultural difference. ${ }^{6}$ Overlaid on both these aspects are the differences between the ways in which childhood is imagined and the experience of children is lived. Indeed, these 
tensions require careful unravelling in the specific context of the 1920 s and 1930 s as new universalising ideas about modern childhoods - summarised by Viviana Zelizer in the American context as 'emotionally priceless' but 'economically worthless' - began to generate support in South India and inform policy and discourse. ${ }^{7}$ Accordingly, this article considers the way in which childhood was imagined and defined by South Indians in their autobiographies and, in particular, the ways in which the category of age intersected with gender, class, caste and race as childhood memories were invoked and remoulded. Childhood was both imagined and experienced through these differentials of social identity.

Childhood was central to what David Pomfret calls the 'iconography' of empire in South Asia. 8 While the 'native' was infantilised in justification of paternalistic colonial rule, colonialism was also a project of the 'white adult saving the brown child from the brown adult' in which the claimed protection of the innocent and vulnerable played a central role. ${ }^{9}$ By the twentieth century, the debates over who had the legitimate authority to define childhood and to intervene in children's lives had come to mirror wider colonial tensions over gender, race, sexuality and political control, seen clearly in the controversies surrounding the age of consent. ${ }^{10}$ Ishita Pande argues that the 1929 all-India Child Marriage Restraint Act was a defining moment, which witnessed the emergence of a new understanding of modern childhood defined by sexual innocence and specific 'numerical values' or 'digits of age'; this in turn had been influenced by new universalising discourses of rights, encapsulated in the League of Nations Declaration of the Rights of the Child 1924. ${ }^{11}$ However, the 1920 s and 1930 s can be characterised more broadly in relation to new developments in the conceptualisation of childhood and the emerging modern welfare state. The introduction of dyarchy under the 1919 Government of India Act and the emergence of a reinvigorated and newly vocal anti-colonial movement enabled Indian legislators in the provinces to introduce a series of measures including the Madras Elementary Education Act and the Madras Children Act of 1920 - designed to encourage compulsory education, to regulate acceptable knowledge in school and to protect children at risk. ${ }^{12}$ This contributed to a new consensus regarding the individual child: as learner and therefore as intellectually malleable, as 
physically vulnerable and sexually innocent, and as characterised by play and thus as distinct from adults rather than an inferior form of adulthood. Additionally, a new discussion of the child as future citizen and thus worthy of financial and emotional investment by the nation-state emerged, although this coexisted with competing discourses that emphasised the child as object of state welfare or as merely the adjunct of the family. ${ }^{13}$ This article argues that, in contrast to the universalising agenda suggested by official archives, analysis of autobiographies reveals the gradual and uneven ways in which these new ideas about childhood were coalescing and older ideas about social categories were being reformulated.

\section{Methodology and the 'chasm between my boyish days and now'. ${ }^{14}$}

Historians of childhood have drawn attention to the considerable methodological challenges of using oral history interviews, the written record or material culture given that they often reveal more about the strategies of adults than the experiences of children. ${ }^{15}$ However, new studies, particularly in the field of education, have demonstrated not only how knowledge is constructed for and about children, but also how they have contributed to this in a variety of nuanced ways. ${ }^{16}$ Moreover, the 'act of listening' - to this often ignored but numerically significant social group - is both methodologically and politically important. ${ }^{17}$ This article draws on the memoirs of 55 individuals, selected because the authors were born between 1910 and 1940 and lived their childhoods in South India, loosely defined as the Tamil, Telugu, Kannada and Malayalam speaking areas. All have been accessed in English but were published in India, the majority reflecting middle-class adulthoods and the exceptional educational levels of the authors. Four of the Dalit autobiographies were translated and published in Britain as part of a wider Dalit literature project, and they are supplemented by two further volumes of Dalit literature edited by K. Satyanarayana and Susie Tharu. ${ }^{18}$ These volumes provide an important insight into a community often under-represented in the literature but are not without problems. While the experiences of Dalit writers who were children in the 1950s and 1960s undoubtedly reflect experiences from the late colonial period, it is important not to ignore the impact of the significant constitutional and socioeconomic changes of the post-independence years. To do so would increase the 
marginalisation of Dalit communities by assuming homogeneity and by dehistoricising their experiences. Multiple autobiographical memories of different childhoods together provide a fragmentary and imperfect perspective that nevertheless interrupts wider patriarchal structures and contests accepted norms of power and identity. They offer an alternative emphasis to the sources produced by the state. ${ }^{19}$ In conversing with these muted voices, interrogating them and thereby identifying other norms, structures and forms of organisation, this article will articulate perspectives that act 'alongside' more conventional speech, disrupting the 'simple dichotomy between silence-speech' whilst still recognising the influence of the historian's own voice and concerns. ${ }^{20}$

Indian autobiographies are what Antoinette Burton calls 'archives-in-themaking', literate sources which fulfil a particular narrative function detailing social and cultural change. ${ }^{21}$ Rather than a self-reflective genre as associated with the Western or Bengali traditions detailing the emergence of the individual self, most South Indian autobiographers portray their life as 'individual destiny and the social matrix in which it is embedded. ${ }^{22}$ The writers used this 'idiom of non-uniqueness' both to veil the self and by doing so to claim their historical authenticity as typical thereby 'appropriating' the genre of autobiography to produce a history of the social changes that they had witnessed..$^{23}$ This means that personal details, such as emotional reactions or emergent sexuality, are often deliberately excluded from the accounts, and choice of autobiography as a literary genre is assumed to reflect the author's commitment to modern values and shift 'to a temporality of newness and vibrancy' in contrast to a static past. ${ }^{24}$ Childhood memories are particularly significant, both as a 'narrative tool of defamiliarisation' to emphasise a past which no longer exists, and because of the particular claim to 'believability and authority' because events are remembered through the innocent gaze of the child. ${ }^{25}$

A. R. Venkatachalapathy argues that Tamil autobiographies are explicitly structured around a binary of the difference between antha kalam/intha kalam, or 'those days/these days' which explicitly demonstrates social transformation, often between the binaries of tradition and modernity, agency and passivity. ${ }^{26}$ The binary 
between 'today' and 'those days' is reflected in many aspects of social life which affected children, including education, family life and relationships within the village community, but also mirrored the careers of the writers, many of whom moved from a rural community to the city for tertiary education. Jagannath Mohanty, as a pedagogue, argued:

My objective in writing this book was to show the children the life and society during my childhood days. I wanted them to know how children particularly in the village grew up then, what difficulties they faced, what joy and sorrow they experienced, who was there to act as their guide and philosopher on life's puzzling path. ${ }^{27}$

This situates the memories of childhood not only in contrast to adulthood, but in contrast to the childhood of 'today' and thereby calls into question the idea of childhood as a universal condition by locating it in a particular time and place. This was reflected in the number of those who wrote specifically for their grandchildren or who mentioned this difference explicitly. ${ }^{28}$ Yet the chasm recognised by $\mathrm{K}$. Veeraswami between 'today' and those 'boyish days' and the description of wider social change is also a 'tool', telling a particular story which is both nostalgic for a lost childhood and is 'rooted in Nehruvian optimism about the transformative possibilities of nationhood', in which children as future citizens had the potential to transform an independent India into a variety of, often competing, utopias. ${ }^{29}$

Memoirs also offer an insight into the histories of groups under-represented or even 'silenced' in the traditional archive and are often explicitly used by these communities as a genre of resistance. ${ }^{30}$ Twenty-two (40\%) of the autobiographies were written by high caste Brahmins, many of whom write self-reflectively about their privileged position in society. A further eight (14\%) were authored by Dalits and tribal peoples and nine (16\%) were written by women. Both M. Subbamma, a feminist social worker, and A.N. Sattanathan, an activist for the rights of Other Backward Castes, explicitly use the genre as a campaigning tool to describe childhoods they perceived to be marginalised. ${ }^{31}$ Similar to earlier Bengali women's 
autobiographies, this was reflective of a claim to 'autonomy' and 'subjectivity' despite a narrative style which predominantly seeks to detail a narrative of the social and cultural change of the 'new nation' rather than the emergence of the reflective self. ${ }^{32}$ Dalits use autobiographies to encourage 'an empowering construction of Dalit selfhood' and thereby destabilise current and historical power relations by portraying the underlying common humanity of the Dalit community as complicated equals rather than 'objects of compassion', thereby 'staking a claim to a public voice and to self-respect'. ${ }^{33}$ The memories recorded become both a private source and a 'collective biography', a portrayal of the changing and tangled relationship between the individual and the local community, as the writers portray themselves as relational within the multiple subjectivities of gender, nation, race and class. ${ }^{34}$ Autobiography therefore provides a unique opportunity to access 'snapshots' of voices 'muted' in the traditional archive. ${ }^{35}$ Although deeply mediated through time and later personal experience, it contributes to a deeper understanding of the relationship between the construction of childhood through adult memory, the experiences of children at school and at home, and the ways in which children understood their identities as children within a wider community. ${ }^{36}$

\section{Days of innocence: constructions of childhood}

Many of the authors sought to define the 'essence' of childhood, its intrinsic qualities and characteristics and the impact childhood experiences had on later adult decisions, in ways which both valorised their own childhoods and clearly defined themselves as adults. President Kalam's recollection of 'days of innocence' necessarily revealed his adult understanding, but also reflected his later engagement with popular discourses of childhood through his campaigns linking education, youth and nation-building. ${ }^{37}$ In modern discourses of childhood the distinction between adulthood and childhood is clearly defined, either by 'digits of age' or by a significant life event. It is noteworthy that none of the writers attempt to identify either when this transition happened in their own lives or when they considered it should be. This could reflect the lack of legal clarity, a reluctance to engage with political debates around the age of consent for marriage, a veiling of intimate details such as puberty, or a recognition of youth and adolescence as a fluid and undefined category. While 
not prepared to demarcate its boundaries, the authors still constructed childhood distinctively as a time of intellectual curiosity, characterised by learning through the tangible and the visible. ${ }^{38}$ Childhood was also remembered as a time of emotional security, within clearly defined boundaries set by adults. Life was remembered as not just 'narrow, insulated' but also 'real and meaningful', although K.P.S. Menon admitted the dangers of nostalgia, for 'in the evening of one's life, one is apt to exaggerate the glory of the morning. ${ }^{\prime 39}$

By contrast, K.M. Panikkar saw childhood as the most 'distressing stage of life' defined by a lack of rationality and inability to self-regulate emotion appropriate to the adult world, particularly 'jealously, rivalry and greed'. ${ }^{40}$ Childhood was remembered by others as a time of cruelty, selfishness and untruth - cheating in games, for example, was described as a 'childhood luxury' - from which children have to be regulated and moulded into adult norms of civilised behaviour. ${ }^{41}$ Irrational fear was a frequently mentioned childhood emotion, often involving animals such as leeches, horned buffaloes and lizards. ${ }^{42}$ Menon, later India's first Foreign Secretary, detailed his 'sheer terror' at the local ghost stories. ${ }^{43}$ The cartoonist R.K. Laxman argued that frightening children was essential to their normal psychological development and that 'it is a wonderful experience to be frightened out of one's wits', even if only to attain adulthood by learning to control such anxieties. ${ }^{44}$ The supposedly childish failure to distinguish between imagination and reality also meant that marginalised adults, such as snake charmers or local alcoholics, were remembered particularly vividly and could be used by parents as disciplinary strategies: Hanuman performers, for example 'were employed to frighten children into good ways, with their macabre voices and forebodings'. ${ }^{45}$ Emotional immaturity - and associated constructions of primitive savagery and irrationality was emphasised as a particular characteristic of childhood, in ways which juxtaposed the child with rational adulthood. ${ }^{46}$ Children also perceived themselves to be powerless in the face of adult discipline, routine and authority, both at school and within the home, and childhood was remembered as a time of 'fears and secrecies and furtive acts' which were 'adopted instinctively for survival in a world dominated by adults'. ${ }^{47}$ This combination of emotional immaturity and the enforcement of 
power through generational hierarchies appears to reflect the commonalities or structural position of childhood and experience of all children. ${ }^{48}$

\section{Days of mischief}

To characterise childhood as 'days of mischief' demonstrates the centrality of play to normative constructions of childhood. It is still debated whether this association between childhood and play reflects a universal developmental pattern or is particularly associated with modern ideas of childhood and leisure, especially in defining the boundaries between child and adult. ${ }^{49}$ In the South Indian context, a discussion of play was used by the authors to contest assumptions that South Asian childhoods were defined by work and therefore 'lack' as insufficiently 'childlike'. ${ }^{50}$ This in turn contributed to the influence of this normative assumption and further Othered children, most likely the majority, whose days were primarily characterised by work. ${ }^{51}$ At the same time, Ruby Lal emphasises how 'playfulness' blurred the binaries between juvenile and adult, work and play and was used to contest the 'structures of power' at home and in school. ${ }^{52}$ For example, Viramma as a Dalit girl worked in the local Reddi house, and afterwards played with the higher caste girls who lived there. She remembered:

I played at being a dog for them and ran around on all fours while they chased me, laughing, with sticks in their hands. They often asked me to tell them stories: I knew a lot more than they did. ${ }^{53}$

The girls used role play simultaneously to transgress caste distinctions and to reinforce village power relations, using the Dalit child as not fully human, but also providing Viramma with a sense of self as being able to entertain them in ways not possible in the adult world. Viramma later suggested that rich children had a much more restrictive and propriety-bounded experience of childhood. ${ }^{54}$ Festivals, in particular the South Indian celebrations of Deepavali and Pongal, likewise provided a moment for engagement with other children across the wider village community. ${ }^{55}$ However, while the specific rituals themselves appear to have been enjoyed by all, the provision of entertainment by outsider communities -- such as dancing by cowherds or fishermen, Muslim wrestling, or epics provided by storytelling castes -- 
appears to have reinforced both the child's sense of belonging and their awareness of communal difference. ${ }^{56}$

In general, play was viewed as a collective experience in which children were 'gangs', 'a forgotten herd', 'a happy bunch' or even 'the damned pack of crows'. ${ }^{57}$ This could involve siblings, cousins or friends in the wider community, sometimes across caste boundaries. ${ }^{58}$ However, most experiences of play reflected wider social categories and even when adults - typically older siblings or uncles - were involved there was still a clear recognition of the boundaries between adult and child. ${ }^{59}$ Differences in space were significant. Women recounted playing at home, often engaging in gendered role play which particularly reflected life in a rural community, acting out marriage festivals and domestic and agricultural chores. ${ }^{60}$ Boys appear to have spent their leisure time outdoors. Activities were collective, for example climbing trees, picking wild berries, flying kites and team sports such as cricket or football. ${ }^{61} \mathrm{~K}$. Sreenivasan's recollections included complicated competitive games with mango seeds and group swimming in the big irrigation wells. ${ }^{62}$ Noticeably the games described in detail, such as Chinni Dandu, were those less often played by the time the autobiographies were published. ${ }^{63}$ The material culture of play was linked closely to the natural materials of the village and manufactured toys, such as K. Das's doll's house, Laxman's toy cars or Sreenivasan's wooden pushcart, were particularly prized and often an indication of wealth. ${ }^{64}$ Animals were frequently involved, ranging from grasshoppers through chameleons and birds to more domesticated animals, such as peacocks, cats and dogs, to the exotic, such as a monkey or even an elephant, which again reinforced this association between childhood, nature, the primitive and the savage. ${ }^{65}$ On the other hand reading books featured extensively in the leisure activities of both boys and girls, sometimes as individuals but often within the family and home. ${ }^{66}$ The experience of play appears to have provided opportunities to identify the commonalities of childhoods and the experience of children as a collective group, in turn emphasising the contrast to the individual self of the rational adult, but often in ways which reflected rather than transcended wider social divisions of community and gender. 


\section{Days of learning}

Memories of childhood related principally to formal education, reinforcing the synonymy between modern childhoods and schooling. Within the Madras Presidency only $33 \%$ of boys aged between 5 and 15 years were in school in 1931, highlighting how unrepresentative the autobiographies are in that $87 \%$ of authors continued to tertiary education. ${ }^{67}$ Many were the first generation of their family, and even of their village, to be formally educated to even secondary level. This self-identity as 'schoolchild', though never formally acknowledged, not only enabled their social progression and gave them the skills required to record their childhood experiences but differentiated the writers from their peers from a very young age. The narrative distinction between those days/these days is mirrored in the clear binary between the pia/ or village school with its large classes, informal control and rote learning representative of traditional schooling and the experience of the majority, and the routine, equipment and enlightened discipline associated with more modern secondary education. ${ }^{68}$ The material life of the school reinforced this, contrasting the desks, slates, 'extensive playgrounds and shady avenues of trees' of the secondary schools with the palm leaf documents and literacy learned through drawing letters in the sand in the pial school. ${ }^{69}$ The memories of secondary schooling dominated the accounts, described as 'easily the formative years of my life', and contributed to the explicit belief of many of the autobiographers as adults that education was essential to nation-building and that they personally embodied the success of that social reform. ${ }^{70}$ The extent to which elementary education provided them with a new identity while still a child is less clear, although the description of being the cleverest child at school was evidently important as an adult.

The space given to describing the detail of elementary education, including the minutiae of individual lessons and memories of teachers, provides some indication of its prominence in children's daily lives and routines. ${ }^{71}$ To be a schoolchild may have been a new and privileged identity to be celebrated in later life, but the abiding memory for the many was the uninspiring boredom of schooling and monotony of rote-learning - N.G. Ranga, for example, argued that the Kannada and Telugu scripts were so complicated that whoever devised them 'couldn't be a 
friend of children nor could he be so keen on universal education'. ${ }^{72}$ Schooling further emphasised the collective experience of childhood as dominated by adults, and the teacher emerges as a clear subject of childhood memory, the personification of the school and of adult authority. ${ }^{73}$ Elementary teachers were remembered in three categories, the first of which consisted of Education Department recruits who were intent on the moral and social reform of their charges. Sreenivasan's teacher, for example, was enthusiastic about 'civilisation through games and sports' and he recounted an heroic attempt to teach the boys football on a pitch with a bullock-cart track through the middle and a thorny hedge on one side, meaning that more time was spent repairing punctures and waiting for traffic to pass rather than playing. He wrote: 'under the handicaps, even the persistence of a Robert Bruce might have weakened, but our headmaster persevered for months'. ${ }^{74}$ The second were so-called traditional teachers, usually referenced as 'intellectually mediocre' and inclined to excessive physical punishment. ${ }^{75} \mathrm{~A}$ third group were men who 'had an absolute passion to teach and mould a young mind' and were remembered as a 'lasting influence', to whom the author owed a 'special debt' because of their pedagogy and pastoral care. ${ }^{76}$ Characterised formulaically as 'a gentleman and a scholar' these teachers were respected as an integral part of the village community. ${ }^{77}$

The school encouraged the solidarity of all children in opposition to the adult authority of the teachers, reinforcing generational hierarchies and creating a new institutionalised identity as a community among an otherwise disparate group. ${ }^{78}$ School was also remembered as a place where children could express their own agency, as a child within a group of children, and the Dalit writer C. Kesayan remembers the 'unjust exercise of authority by elders' (often within his caste) as central to his experience of childhood. ${ }^{79}$ This was not an emergent 'subaltern consciousness' but a means of resistance to teachers and an oppressive system of learning and subordination grounded in the everyday decisions of children, and their attempts to undermine adult authority through the 'weapons of the weak'. 80 Mimicry and laughter were key tools for this, enacted through caricatures on the blackboard, graffiti and practical jokes and N.C. Yati reflected that it was 'normal and healthy' for a child 'not to conform'. ${ }^{81}$ There were memories of whispered conversations, of 
throwing paper darts and pieces of chalk and fighting, crucially always as a collective, reinforcing the camaraderie of the group. ${ }^{82}$ When, for example, Sattanathan played a practical joke on the teacher, he received the silent support of all his fellow students, relying on their silence for protection and depending on their mutual antipathy towards the teacher, despite the variety of caste backgrounds and usual lack of social interaction, and in the process discovered the thrill of mischief and the risk of punishment'. ${ }^{83}$ More conscious decisions, for example to truant, were less common and more likely to be an individual choice. ${ }^{84}$ Writing as an adult the novelist R.K. Narayan suggested that he chose to miss drill class every Friday and accept the six cane cuts every Monday in punishment, but also elected to attend scripture classes because the bible stories caught his imagination, while explicitly rejecting the anti-Hindu rhetoric of the mission teachers. ${ }^{85}$ Of minor significance in themselves, these incidents gave children a perception of themselves as having contemporary agency in a world of school where the focus remained on what they should 'become' through education, and often reinforced a sense of collective identity as children in relation to the adult authority of the schoolteacher, and his allies the parents.

\section{Days of work}

The new association between the school, intellectual plasticity and normative childhoods in the minds of bureaucrats, politicians and ultimately the autobiographers themselves hardly reflected the reality of the lives of the most children. Two-thirds of children remained outside the reach of formal school education and learned primarily within the family and workplace. ${ }^{86}$ By constructing education and work or 'child labour' as mutually exclusive and by increasingly defining childhood by participation in formal education, policy makers - and often historians too - ignored the lives of the majority who combined both. ${ }^{87} \mathrm{~A}$ number of authors engaged in agricultural work on a seasonal basis, for example in the betel leaf plantation, paddy harvest or the brick kilns. ${ }^{88}$ Sattanathan reflected both on his 'special privilege as an educated person' which meant he could help his family calculate the wages and produce, and his happiness as a younger boy when delegated to keep birds from the harvest - 'a delightful change for the little boy from 
school'. ${ }^{89}$ Kalam recounted his exhaustion but also pride in being 'a working boy at eight' as he contributed to the family income by fitting his newspaper delivery job around his school schedule. ${ }^{90}$ Often these activities were remembered not as a failure of the family to provide, but as enhancing the child's feelings of self-worth as a contributor. ${ }^{91}$

Despite the predominance of their numbers and their concern to legislators (for example in discussions around the Factory Acts), 'working children' increasingly appear as a transgressive category. Working children fell short of what was progressively perceived in discursive terms to be the universal standard of childhood, common across cultures and reflective of the Geneva Declaration, which assumed the child was learning and at school and should be provided for by, not a contributor to, the family. ${ }^{92}$ Many girls participated in domestic duties: looking after the house and the younger children or even producing handicrafts to sell. ${ }^{93}$ The first female Badga (tribal caste) politician, Akkamma Devi, recalled learning her lessons outside the school building while caring for her baby brother and the impact on her mother's workload when she secured a place at the local convent school. ${ }^{94}$ All the Dalit autobiographies detail unskilled work for children. For example K.A. Gunasekaran sold mangos or neem seeds or collected dung as fuel from the bullock carts outside the cinema. ${ }^{95}$ Viramma received no formal schooling and was expected to look after the younger children before learning to harvest vegetables. ${ }^{96}$ The childhood memories of work highlighted its menial character, and the ways in which contributing as 'mini adult' to the family income was important to the child's selfworth. ${ }^{97}$ All the autobiographers situated childhood work as a feature of 'those days', often to demonstrate the comparatively privileged position of the modern children of 'these days', ignoring the continuing presence of child labour in South India. ${ }^{98}$ All see modern education as the primary solution to inequality, and an important aspect of nation-building, claiming an authentic opinion on the basis of their own lived experience. ${ }^{99}$ The autobiographies establish the multiplicity of children's experiences, in contrast to the growing universal norm of modern childhood which increasingly influenced state discourse and interventions regarding children, but they also reveal the commitment of the autobiographers to that universal norm. 


\section{Days of family}

The binaries of education and work, and of home and school, ignore the importance of the family as a site of practical education and socialisation into the identities, traditions and hierarchies of the community. Suspicion of education outwith the formal setting of the schoolroom was a widespread feature of colonial modernity, a trend reflected in the historiographical literature on education. ${ }^{100}$ It also reflected a wider ambivalence towards the Indian family. The Indian home was integral to the modernising project, alternatively conceptualised by middle-class reformers or colonial officials as a site of ignorance, corruption and threat or as the private area for the preservation of Indian cultural and religious purity, usually according to the class and educational levels of the family in question. ${ }^{101}$ Whilst at the level of state discourse authority in the home was situated in 'parents', perhaps assuming a nuclear family structure becoming increasingly popular among the Bengali middle classes, in the autobiographical memories it was more often the role and authority of the extended family which was significant. ${ }^{102}$ Children from artistic castes were raised in the guru-sishya tradition, under the tutelage of a parent or guru whom they revered as father. ${ }^{103}$ Uncles had a protective and financial role and older, married, sisters often assumed the responsibility of 'assistant mother' or 'effective guardian' to their younger brothers. ${ }^{104}$ It was, for instance, K.L. Raghuramaiah's 'uncles who were proud that we were the first educated girls in the family' and her mother's younger sister who was her primary caregiver in her early years. ${ }^{105}$ Grandparents were remembered as the recognised site of secular and religious wisdom on account of their age, experience and piety, at times even in defiance of parental authority. ${ }^{106}$ Panikkar recounted:

when he [his uncle] found I was playing truant one day, he tied me to a pillar and left me with paper and books, before going out. As soon as uncle disappeared, grandmother came and set me free, but tied me up again before uncle returned for lunch'.

This continued for a week until they were discovered. ${ }^{107}$ Older women were particularly important in socialising younger women into appropriately gendered and generational forms of behaviour including pre-marital chastity or sex education, as 
well as providing emotional support. ${ }^{108}$ Viramma, for instance, remembered her first menstruation when she was confined indoors for eleven days:

in the evenings, a group of old and young women, including Arayi's and Nagamma's grandmothers, would come and sit near the tinnai [or verandah] and sing funny, rude songs. By their singing, they were teaching me what was in store and how my husband would "use" my body. I was glad to be out of sight in my cubbyhole because hearing them made me ashamed. Interestingly, she comments that while she received explicit detail about sex, pregnancy and childbirth were never mentioned. ${ }^{109}$

The role of the extended family was particularly important as storytellers, socialising children into family values and traditions, whether religious, moral and secular. ${ }^{110}$ Many authors remember 'the old Tamil songs and stories' and their impact on the imagination and 'the aesthetic life' of the child. ${ }^{111}$ Sreenivasan noted the impact of observing a routine of communal prayer:

Every Hindu child absorbs the myths, the traditions, the superstition and the morality along with his or her mother's milk. Participation in ritual and ceremonials is so much a part of one's life from very early childhood that they enter the subconscious. ${ }^{112}$

The adult voice of the author clearly differentiated between individual belief as adult, and the religiosity of storytelling and ritual as a collective experience which affirmed the child's place in the community, strengthened a sense of belonging and reemphasised its power structures. ${ }^{113}$ Yati recounted his grandmother reading the Bhagavad Gita in the evening:

Children gave up their pranks and grownups stopped gossiping. All sat and listened to the sonorous recitation of grandmother who was gifted with a musical voice. I did not understand what she was reading, but I liked the calm atmosphere and the picturesque setting of the evening prayer. ${ }^{114}$ Oral knowledge was often associated with people who were perceived as socially inferior, such as older widows, servants or lower castes, or even grandparents now perceived to be outdated in a modernising world. ${ }^{115}$ However, Sattanathan remembered that despite his illiterate father's 'astounding' knowledge of the Hindu 
epics, it was he who read the Hindu epics to the family every day. ${ }^{116}$ The schoolchild became both a source of family pride and economic potential and a threat to the generational hierarchies of knowledge within the family, as the religious and experiential wisdom of the elders was made to give way to the modern scientific knowledge of youth. The association with 'those days' of grandparents, religiosity, emotion and a pedagogy based on repetition was also positioned in stark contrast to 'these days' of a modern education system and the rational, progressive, but perhaps less emotionally stable, world of the modern child.

It is important not to over-valorise the family, thereby reinforcing nationalist narratives surrounding the private domain as the site of pure Indian tradition and unfailing emotional support. For many children, especially those living in poverty, the literature on juvenile delinquency makes clear that the home was a space of disorder and unpredictable tensions, a suggestion reinforced by the number of relatively young children living outside the familial home. ${ }^{117} \mathrm{~A}$ number of writers detail instances of domestic violence, particularly the Dalit autobiographers: Mogalli Ganesh recalled that his father was so cruel that all three of his wives committed suicide, while N.K. Hanumanthaiah remembered his father's alcoholism and physical abuse of his mother. ${ }^{118}$ However, only a few chose to record familial tension or to see themselves as the victim. ${ }^{119}$ This is more a reflection of the nature of autobiographies as a source material and the desire to portray the outward 'respectability' of the family than an unproblematic representation of the past. ${ }^{120}$ Indeed, Viramma described a childhood characterised by labour, hunger and poverty, but spent a lot of time with her friends and argued 'our days of happiness flowed past like this, our days of games and laughter'.121 This categorisation of children within a binary as either at home or on the streets appears to result from colonial and post-independence anxieties about child-saving and reform. In the context of contemporary street children, research reveals that this underestimates the continuing ties with the natal home and the importance of a mother's love, or memory of a mother's love, in the children's worldview, but also the complex intertwining of violence and tenderness in many impoverished households. ${ }^{122}$ The family could be both a site of continued instability and trauma meaning that children 
chose to sleep in a shelter or on a railway station platform, and simultaneously a place where children maintained strong family ties. ${ }^{123}$

Leaving the family signalled the de facto end of childhood for many middleclass children and was a clearly a definitive moment of dislocation in the lives of many. For boys this usually meant continuing studies at a secondary school in town, while for girls this more often meant cohabitation, following an earlier formal marriage agreement. Both distanced them from the family - through new homes and ultimately a new identity as 'wife' or as 'educated'. While the writers followed a pattern often previously witnessed in older siblings, this made the wrench of leaving and the subsequent change in worldview no less traumatic. ${ }^{124}$ The gendered nature of memory recording is demonstrated in the more extensive details of marriage, sex and children provided by the female autobiographers. ${ }^{125}$ Yet few clearly specify a definitive end to childhood and there is very limited reference to sexual innocence or emergent sexuality. Only the Dalit writer Viramma gives explicit details, although Sreenivasan learned about sex from watching animals in the rural community and from listening to the servants, which - along with his grandfather's mistress reinforced the commonly held stereotype of low caste women and sexual availability. ${ }^{126}$. Only social reformer Dr Muthulakshmi Reddi and the novelist Santha Rama Rau used their autobiographies to demonstrate their principled opposition as females to early marriage. ${ }^{127}$ This appears to reflect a conscious veiling of private life from the public gaze, fitting with the wider constraints of Tamil autobiographical writing and contrasts distinctly with the writings of high caste Northern Indian women who used their autobiographies to campaign for an increase in the age of consent. ${ }^{128}$ Childhood was thus described predominantly as a time of physical and emotional security, in which the family was remembered as a nostalgic space of safety and protection left behind in 'those days' for an uncertain, modern adult world.

\section{The politics of identities in childhood}

In his collection of academic autobiographies of childhood, M. Karlekar argues that 'one of the great joys of childhood is that one is blissfully unaware of the tensions 
and problems of the adult world', children being unconscious of financial responsibility, but also of the political context of identity and difference. ${ }^{129}$ Sen extends this further, arguing that childhood is a time when it was 'easier' to interact across boundaries and 'walk in the shoes of the recognised Other'. ${ }^{130}$ This contests Krishna Kumar's argument that adults increasingly used children's bodies as a site of 'symbolic and real battles' specifically 'emanating from identity conflicts', at a time when the 'language of community identity' was becoming increasingly potent in the mobilisation of political resources and the exercise of state power. ${ }^{131}$ This perception that children are less aware of, or better able to transcend, adult boundaries of class, caste, race and gender reinforces the association of childhood with political innocence, irresponsibility and a primitive understanding of power structures in ways which reflect colonial constructions of savagery, primitive peoples and civilisational hierarchies, though with the possibility of future redemption through attaining adulthood. ${ }^{132}$ This construction then forms children as a group, as themselves a marginalised community bounded and defined by age but oversimplifies their understanding of community and identity, their complex interactions and the wide variety of their lived experiences. This overwhelming and often overtly nostalgic association of political innocence and childhood ignores the roles played by other socially defined categories such as race, nation or gender in the lives of children, and strengthens a normative but racialized conception of innocence, closely linked to nineteenth-century constructions of white supremacy. ${ }^{133}$ The autobiographies provide a further insight into the differing communities in South Asia and into the way identity was experienced, contested and learned by children, particularly within the public space of the school and village community.

The overt politics of colonial difference and racial hierarchy so often emphasised in the literature on colonial childhoods were remembered in only a few autobiographies, reflecting the rural context of most childhoods. ${ }^{134}$ Das wrote that Indian children were treated with physical cruelty by their white and mixed race peers at school and were regarded as inferior by staff, while Nataraja Guru recalled frequent fights between differing racial groups. ${ }^{135}$ Rau recounted vividly her brief experience of school aged five years. Renamed Cynthia because the teacher 
objected to the name Santha, she refused to talk about school with her family: 'I was so pleased to be home and to have left that peculiar Cynthia behind that I had nothing whatever to say about school', feeling almost disembodied from her new identity. ${ }^{136}$ The incident was short-lived and school terminated when her older sister walked out, objecting to the British teacher's racialised assertion that all Indians cheat in exams. However, contact with white teachers was rare and even mission staff appeared to have been predominantly Indian, a product of the indigenisation of mission work by the twentieth century. ${ }^{137}$

There are also few memories of active engagement in opposition to British rule and limited evidence of the formation of a new national identity. A number of the writers remember seeing famous personalities such as Nehru, Gandhi and Sarojini Naidu at Congress party rallies. ${ }^{138}$ There were memories of parental participation in the freedom movement: K. Shridharani's mother left the family to live in an ashram and Das's grandmother donated the family jewellery to Gandhi's Harijan fund, while J. Mohanty remembers his parents' first experience of voting. ${ }^{139}$ Rau's elder cousin Radha dyed the borders of her white muslin saris orange and green as evidence of her nationalist affiliations; this was primarily significant for the whispered family conversations about the impact it might have on her marriage prospects. ${ }^{140}$ Similarly, while children were doubtless involved in anti-colonial politics - seen most dramatically in parallel government at Isoor - and there were clear attempts in travel magazines for children to forge emotional connections between children, the nationalist leadership and the concept of India as a nation, most political involvement appears to be as adolescents and students and was often initiated by teachers. ${ }^{141}$ Mohanty had clear memories of joining the Vanar Sena or monkey brigade, the children's wing of the Congress party set up by Indira Gandhi in 1930. ${ }^{142}$ However, R.V.M.G Ramarau's decision to join the Congress party involved a much more tangled, and self-reflective, set of motivations and was a combination of rebellion against 'parental oppression, the national humiliation imposed by foreign domination and the suppression of justice and freedom, truth and beauty', undoubtedly assisted by his father's loyal support for the British as Raja of Pithapuram. ${ }^{143}$ In general, however, the future citizens of India were the recipients 
of state and parental investment and were imbibing new loyalties, rather than actively shaping the national future.

Religious antagonism was increasingly politically important by the 1930s and with the partition of the subcontinent in 1947 came to dominate both historical and autobiographical accounts. Kalam described his personal experience of religious discrimination as a Muslim in both his autobiographies, using this incident to contribute to his campaign as President of India for the peaceful co-existence of religions. ${ }^{144}$ Although his father was Imam of the local mosque, Kalam's three friends were from orthodox Brahmin families, an extension of his father's close friendship and regular contact with the local Hindu and Catholic priests. Kalam recounted that in 5th Standard a new teacher separated him from his friend after noticing the material symbols of their religion - the Muslim cap and the Hindu sacred thread. In the first account the father of his friend, the Hindu priest, rebuked the teacher 'that he should not spread the poison of social inequality and communal intolerance in the minds of innocent children'. ${ }^{145}$ In the second account, all three religious leaders confronted the teacher with their concern that intolerance was allowed to 'infect the minds of the youngest members of society'. ${ }^{146}$ While the two versions demonstrated subtle differences not unlike the retelling of oral history, they also re-emphasised Kalam's personal belief that discrimination is a virulent disease and learned behaviour and that the plasticity and naivety of children's minds both provided the potential to overcome prejudice and made them uniquely susceptible to imbibing it. This was a 'strategic use' of childhood to make a political claim that the shared experience of childhood was sufficient to overcome adult violence, whether physical or intellectual, and the adult structures of caste and religious identity, both inside and outside school. ${ }^{147}$ P.C. Alexander, later Governor of Tamil Nadu then Maharashtra, remembered both the celebrations of his own Syrian Christian community, but also participating in other religious festivals. This 'culture of religious tolerance and communal harmony...greatly influenced' his outlook in later life. ${ }^{148}$ The suggestion that differing identity groups were natural but intolerance was learned mirrored the new constitution of 1950 which guaranteed equal rights for all children irrespective of community. It reflected a wider belief among the educated Indian 
elites - including Kalam and Alexander, as well as more prominent figures such as Gandhi and Nehru - that children as 'future citizens' provided the solution to communal discord. For these writers, the demarcation of 'those days' of childhood as preceding the rupture of partition in 1947 provided a nostalgic, but orientalist, memory of a harmonious past that middle-class Indian politicians were eager to recreate, in contrast to communal violence which accompanied India's assumption of adulthood. 149

Gender difference appears to have informed all aspects of childhood and by the 1920s the 'girl-child' was a specific target for state intervention. As noted, girls' experiences of play, of marriage and of home life reflected gendered constructions of their appropriate roles, often particularly enforced by socialisation within the home. While it is widely accepted by historians and contemporaries that girls had limited access to formal schooling this was not reflected in the autobiographies, in which only four remember there were no girls in their local village elementary school. ${ }^{150}$ Of the female authors, only the Dalit Viramma did not attend elementary school. In general teachers were supportive, with opposition most commonly coming from male peers. ${ }^{151}$ Male writers frequently mentioned the attendance of girls in the village school but in the context of co-educational schooling, which would account for their invisibility in the Public Instruction reports. ${ }^{152}$ Certainly few progressed to secondary education and girls such as Muthlakshmi Reddi or Akkamma Devi were exceptional, both educated to university level and later involved in politics. In both cases this reflected both their personal commitment and the insistence of their reforming fathers, despite maternal concerns about the impact on their marriage prospects. ${ }^{153}$ By the mid twentieth century, the educational opportunities and outcomes for girls were not only a result of their gender, but also informed by caste, class and locality and often the political ideology of their father.

The most frequently mentioned marker of communal identity in the autobiographies was caste. This reflected the predominantly male authorship, the relatively small Muslim population within the Madras Presidency (7\%) and the continuing potency of caste politics within post-independence Tamil Nadu. ${ }^{154}$ 
Emerging from the relative safety of the family and home, the school became a space in which children came to learn the practical implications of their caste identity. High caste children played with their peers but began to realise that they were an 'educational aristocracy'. ${ }^{155}$ This was reinforced by the material symbols of the classroom including stools near the teacher, mats of palmyra leaves or ceremonial gifts in ways which as an adult Nataraja Guru likened to the experience of apartheid in South Africa. ${ }^{156}$

For many children the school became the space where the inferiority that came with low caste status was learned in new ways and was an abiding and painful childhood memory. By the 1930s schools in receipt of public money were required to accept all children, but many were subject to systematic discrimination and few remained for the four years schooling required for basic literacy. ${ }^{157}$ Dalit children were often forced to sit outside on the veranda or to perform menial tasks for the teacher. ${ }^{158}$ Gunasekaran remembered being publicly humiliated by caste teachers:

Even now it hurts to think about those times when we had to stand up in front of the others in the class, shrinking and cringing. They would reinforce caste identities by labelling us Pallars, Parayars and Chakiliyars in front of our friends who never knew what caste was. ${ }^{159}$

Even measures designed to facilitate attendance were used to reinforce hierarchy, whether the administration of free school meals or the authorisation of scholarship forms. ${ }^{160}$ Sattanathan, a Sudra who was later Chair of the 1971 Other Backward Caste Commission, remembered the Brahmin teachers' attitudes of contempt, notwithstanding their own poor socio-economic status. ${ }^{161}$ He recalled his Brahmin Tamil teacher, an 'obscene petty tyrant' who would 'taunt' lower caste pupils when they made a mistake, producing 'almost a revulsion' towards the subject. ${ }^{162}$ L.Elayaperumal, a Dalit, remembered his Brahmin teacher asking another pupil to mark his work, fearing caste pollution if he touched his slate. ${ }^{163}$ His comment, 'Though I felt hurt, I did not have the strength or courage to raise my voice,' illustrated the difficulties in contesting discrimination when combined with other relationships of power as teacher-pupil or adult-child. Rather than being a modern symbol of rationality and social progress, the village school emerges in the memories 
as the key site where children learned the practical implications of identity and power and were forced to confront their own marginalisation.

The school was situated within the wider caste relationships of the village and ultimately subject to them. For the former Chief Justice of Tamil Nadu, 'those days' of 'amity' 'irrespective of their caste, creed, community or religion' were situated in a happier, but clearly nostalgic, past. ${ }^{164}$ More often, the memories were characterised by pity for those less fortunate rather than an active desire to treat other castes as equals. ${ }^{165}$ Subramaniam, from a dominant Vellalar caste, remembered that the stigma of untouchability was evidenced in all aspects of village life 'and naturally the children carried on this tradition. ${ }^{166}$ Similarly Sreenivasan, from a wealthy Gounder family, considered the extent to which 'every child in the village, including myself, absorbed these social values as part of one's nature, without being aware of it. ${ }^{167}$ Sreenivasan argued that children subconsciously assumed loyalties to community, village and family within the framework of the caste system. As a child, this made him unwilling to question the hypocrisy of his beloved grandfather, who refused to eat food cooked by his low caste mistress. Chakiar recounted how, at the age of eleven years, he and his siblings were rejected as high caste Namputiris and became lower caste Chakiars after his father's alleged extra-marital affair and subsequent suicide. Yet it was only after his retirement that he protested this. ${ }^{168}$ This was also true of Dalit children: L. Elayaperumal remembered the spatial distinctions within the village, and his father's death from cholera after the Panchayat Board officers refused to spray their houses or provide inoculations in their neighbourhood, but accepted his fate as the only possibility of economic security. ${ }^{169}$ The enforced acceptance of social norms as a child and the internalisation of these values made it difficult to overcome that childhood fear as an adult.

Significant moments of discrimination were recorded by the Dalit authors. These were used as part of a strategic attempt by Dalit activists to 'convert the Dalit sorrows into assets' by highlighting examples of daily discrimination as typical. ${ }^{170}$ They were also framed as a pivotal moment of self-discovery, a 'new understanding' and almost as the moment when innocence about adult society and hierarchies was 
lost. ${ }^{171}$ Gunasekaran was beaten on a number of occasions when visiting relatives, being unaware of much stricter policing of caste boundaries in rural areas. ${ }^{172} \mathrm{~A}$ number of years later, Thumbadi Ramaiah remembers the Jain storekeepers who 'would jump at the sight of us like flea-bitten cows', who handed the children their baskets on a pole through the window, and who 'if their children played with us, they would drag them away, slap them for their insolence and make them wash their arms and feet before entering the house'. ${ }^{173}$ He comments 'we did not understand all this and stood watching in stunned silence', recalling both incomprehension and humiliation on the part of all the children involved. Kamal Pokkudan 'learnt something new' when he realised that members of the Harijan Welfare Committee maintained purity-based separation and required him to pay for his tea by dropping his coins in water and recalled the threat of violence when he unthinkingly shared a glass of buttermilk. ${ }^{174}$ The memories were characterised by a fear of unconsciously transgressing caste boundaries, by the memory of betrayal and by his decision to run away. Similarly, Rettamalai Srinivasan progressed well academically at his school in Coimbatore, but constantly 'pondered over the pain of not even being able to play with other children' through fear of revealing his Dalit background. ${ }^{175}$ While children appear to have been aware of their caste identity in the familiar environment of family and community, learning the practical implications of difference was a harsh experience. This appears to have made the writers very sympathetic to overt caste politics as adults and is intimately connected to the motivations for writing for many.

Contesting dominant discourses through the obscene, the vulgar, the comic and the colloquial has become a distinctive feature of low caste writing in Tamil, although even this is ambivalent, although even this is viewed ambivalently, and can be read either as reclaiming language for Dalit communities or as a further reason for marginalising Dalit writing given the explicit references to women's body parts and bodily functions. ${ }^{176}$ Mimicking the teacher, for example, was a form of protest that enabled fears to be banished not by anger or pity, but by comedy. However, resistance to adult authority appears to be a predominantly male high caste memory, perhaps associated with self-assurance and articulateness. In general, 
children appear to have accepted the identities proscribed for them by adults and were socialised into the boundaries of these identities without overt opposition. ${ }^{177}$ While children often transgressed social norms and identities especially in their friendships, it appears to be the adolescent and adult voice that rationalised and questioned these identities, and the power structures that supported them. ${ }^{178}$ At the same time, the painful process of learning categories and becoming aware of difference and the searing memory of discrimination remained with many of the writers forever.

\section{Conclusion}

Detailed analysis of the collective autobiographies of South Indians who were children in the 1920s and 1930s significantly complicates the accepted narratives of childhood, family and educational policy, decentring elite and adult discourses in favour of more marginalised experiences. ${ }^{179}$ The life writings reveal the extent to which children attended co-educational schools, the persistence and influence of non-modern educational networks and hierarchies within the extended family, and their impact on the emotional security of the child. This bears little relation to the emphasis on colonial education policy, changing funding structures and limited literacy rates that remains the focus of so much of the historiographical literature. Likewise the autobiographies reveal the extent and variety of work carried out by children both outwith the home and within the family economy. In contrast to adultcentred sources which emphasise the morality and prevalence of child labour, for some authors contributing to the family economy was an important aspect of their past self-identity and demonstrated the salience of work in young lives. Nevertheless, for most of the authors elementary schooling was one of the most important memories of childhood and increasingly one of its defining features. While attendance was often sporadic and the quality of teaching frequently abysmal, the school had become the normative space for children and the child was conceived of as 'schoolchild' not only in state but also personal and popular discourses long before the Indian constitution established free and compulsory education for all children in 1950. An attempt to 'listen' to children thus reveals the uneven emergence of this particular universalising idea of childhood in India. 
While liberal state interventions were the most obvious marker of change, it was clear that ideas were shifting at a popular level too but this was uneven and refracted through the experiences of gender, class, caste and, for many, social marginalisation. The autobiographies reflect the wider socio-economic changes of the 1920s and 1930s, and the new disruptions to village life through increased transportation and communication networks, and arrival of the qualified schoolteacher as a new authority figure within village and familial power structures. They reveal changing attitudes and practices to marriage and female education, but also the limitations of well-meaning government and reformer attempts to promote caste equality, revealing both the insidious nature of discrimination and the complicated ways in which experiences of discrimination became internalised by the children themselves. Again, this reconfirms that the 'act of listening' to children's albeit fragmentary memories significantly nuances wider debates around the impact and significance of colonial social policy.

Yet, the association of the child with the school and opposition to child labour within autobiographies also reflected the contemporary priorities and anxieties at the time of writing in the post-independence era. Memories of childhood were used strategically by the authors as a contribution to the nation-building process and as a demonstration of their own commitment to modernity through the separation of adult and child. Constructing ideas of past childhoods through memory - and the device of 'these days/those days' - was thus intimately connected with new understandings of the child as the embodiment of both the future resource and the potential of the newly ambitious nation. 1947 emerges as a moment of distinct change in the imagination of the writers, even when the details of the autobiographies suggested that ideas and practices changed much more gradually and had begun long before independence. Underpinning this writing was a claim to historical authenticity as based on the memories of the innocent child without political agenda, and because of the particular nature of Tamil autobiographical writing and its claims to the impartial documentation of the past. Yet by using this narrative binary the writers are using their own juvenile memories to comment on 
post-independence social change, to reassert their commitment to the idea of childhood as a distinct social category and to reveal the differences between their own pasts and the childhoods of their audience and of the present which they perceive to be characterised by intensive schooling, limited social interaction with peers and often strict religious and caste divisions.

Finally this article has identified the gaps or points of tension within autobiographies - between the ways in which childhood is imagined by the authors and the meticulous and specific detailing of their lived experience. Certainly childhood was remembered as a time of plasticity, of learning knowledge and skills, of 'playfulness' without responsibility at the margins of adult authority, and of understanding the world through the emotions. Yet in reality their lives were often characterised by work, poverty and subordination to adults. The rhetoric of childhood innocence was frequently employed, again, as a characteristic which adults ascribed to their own childhoods, and yet the texts reveal that feelings of vulnerability and powerlessness were much more significant emotional traces. Children remained aware of the divisions of religion, gender and caste even as a child, and learned the behaviours associated with these distinctions. Indeed, it was these intersecting social identities that appear to have been at least as influential in their everyday experiences and choices as the commonality of age.

\section{Acknowledgements}

I would particularly like to thank Crispin Bates, Louise Jackson, Christopher Harding, Tim Ellis and an anonymous reviewer for helpful comments on earlier versions of this article.

1 A.P.J. Abdul Kalam My Journey: transforming dreams into actions (Delhi, 2013), 
35.

2 D. Arnold and S. Blackburn (eds), Telling Lives in India: biography, autobiography and life history (Delhi, 2004), 4.

3 P. Aries, Centuries of Childhood, (London, 1962); V. Balakrishnan, Growing Up and Away: narratives of Indian childhoods: memory, history and identity, (Delhi, 2011)

4 O. Nieuwenhuys 'Editorial: is there an Indian childhood?' Childhood, 16 (2009), pp.147-153. P.Uberoi, Freedom and Destiny: gender, family and popular culture in India, (New Delhi, 2006).

5 For example, S. Kakar The Inner World: a psycho-analytic study of childhood and society in India, (Delhi, 1981). For critical engagement see S. Balagopalan, Inhabiting Childhood: children, labour and schooling in postcolonial India, (Basingstoke, 2014).

6 A. James 'Competition or integration?' Childhood, 17 (2010), pp.493.

7 V. Zelizer, Pricing the Priceless Child: the changing social value of children. (Princeton, 1994).

8 D. Pomfret, Youth and Empire: trans-colonial childhoods in British and French Asia, (Stanford, 2015).

9 K. Vallgårda, Imperial Childhoods and Christian Mission: education and emotions in South India and Denmark (Basingstoke, 2015). A. Nandy, 'Reconstructing childhood', in A. Nandy, Traditions, Tyranny and Utopias, (Delhi, 1992). S. Sen Colonial Childhoods: juvenile periphery of India 1850-1945, (London, 2005).

10 T. Sarkar, Hindu Wife, Hindu Nation: community, religion and cultural nationalism (New Delhi, 2001).

11 I. Pande, 'Coming of age: law, sex and childhood in late colonial India', Gender \& History, 24, 1 (2012), 205-230.

${ }^{12}$ S. Bhattacharya, Contested Terrain: perspectives on education in India, (London, 1998).

13 Balakrishnan, op. cit., 13.

14 K. Veeraswami, The Perils to Justice: a judge thinks aloud (Calcutta, 1996), 351. 
15 M.J. Maynes 'Age as a category of historical analysis', Journal of the History of Childhood and Youth, 1, 1 (2008), 114-124. J Nair, 'The unspeakable violence of Isoor, 1942', in M. John and S. Karakara (eds) Enculturing Law: new agendas for pegal pedagogy (Delhi, 2007), 97-116.

16 Z. Bowen \& J. Hinchy 'Introduction: children and knowledge in India', South Asian History and Culture, 6, 3, (2015) 317-329. C. Ellis 'Snapshots' of the classroom: Autobiographies and the experience of elementary education', Childhood, 18,3 (2011), 384-401.

17 D. Chakrabarty, 'Radical histories and question of Enlightenment rationalism' in D.Chaturvedi, Mapping Subaltern Studies and the Postcolonial (London, 2000), 275;

D. Sreenivas, 'Forging new communities: gendered childhood through the lens of caste', Feminist Theory 11, 2 (2010), 267-281.

18 M. Dasan, V. Pratibha, P. Pampirikunnu, C.S. Chandrika (eds) Oxford Indian Anthology of Malayalam Dalit Writing (Oxford, 2012). R. Azhagarasan Ravikumar (ed.) Oxford Indian Anthology of Tamil Dalit Writing (Oxford, 2012). K.

Satyanarayana \& S. Tharu (eds) Steel Nibs Are Sprouting: new dalit writing from South India (UP, 2013). S. Tharu \& K. Satyanarayana (eds) No Alphabet in Sight: new dalit writing in South India (New Delhi, 2011). Dalits are groups outside the four Hindu varnas, formerly known as Untouchables or Harijans.

19 J.R. Flores, 'Ursula: the life and times of an aristocratic girl', in O. Gonzalez and B. Prema, Raising an Empire: children in early modern Iberia and colonial Latin America (Alburquerque, 2007), 131.

$20 \mathrm{U}$. Butalia, The Other Side of Silence. Voices from the partition of India (London, 2000), 279.

$21 \mathrm{~A}$. Burton, Dwelling in the Archive: women writing house, home and history in late colonial India (Oxford, 2003). K. Hansen, Stages of Life: Indian theatre autobiographies (London, 2011), 27.

22 A.P.J. Abdul Kalam, Wings of Fire: an autobiography (Hyderabad, 1999), xiv. For the Bengali situation see R.C.P. Sinha, The Indian Autobiographies in English (London, 2013).

23 A.R. Venkatachalapathy, In Those Days There was No Coffee: writings in cultural history (New Delhi, 2006), 175. U. Kumar 'Subjects of new lives: reform, self-making 
and the discourse of autobiography in Kerala' in B. Ray (ed.) Different Types of History (Delhi, 2009), 307.

24 U. Kumar, Writing the First Person: literature, history and autobiography in modern Kerala (Bangalore, 2016), 19, 230.

25 Kumar, op. cit., 260. H. Morrison, Childhood and Colonial Modernity (Basingstoke, 2015), 122.

26 Venkatachalapathy, op. cit., 173. Kumar, op.cit., 315.

27 J. Mohanty \& S.Mohanty, In Quest of Quality Education and Literature (Delhi, 2006).

28 For example R.V.M.G. Ramarau, Of Men, Matter and Me (London, 1961), 7. A.M.N. Chakiar, The Last Smārtha Vichāram: a victim's reminiscences (Madras, 1998) preface.

29 S. Sen, Traces of Empire (Delhi, 2014), 91.

30 Arnold \& Blackburn, op. cit., 15. R. Gayathri 'Silent voices: women's perceptions about self and education in late C19 India' in P. Rao (ed.) New Perspectives in the History of Indian Education (Hyderabad, 2014).

31 A.N. Sattanathan, Plain Speaking: a Sudra's story (Oxford, 2007), 4. M.

Subbamma, Fearless Feminist: an autobiography of a social revolutionary (Hyderabad, 1994), 2.

32 P. Chatterjee, Nation and its Fragments (Princeton, 1993), 137.

33 Dasan (et al) op. cit., D.R. Nagaraj, The Flaming Feet and Other Essays: the dalit movement in India (London, 2011), 211. Ravikumar, 'Introduction' in K.A. Gunasekaran, The Scar (Hyderabad, 2009). Sreenivas, op. cit., 271. See also B.M. Puttaiah in Satyanarayana and Tharu, op. cit., 347-368. Tharu \& Satyanarayana, op. cit., 44-65.

34 U. Kumar, 'Autobiography as a way of writing history' in P. Chatterjee and R. Aquil (eds) History in the Vernacular (Delhi, 2008). S. Balagopalan, 'Introduction: children's lives', Childhood, 18, 3 (2011), 291-7, here 295.

35 Ellis, op cit.

36 Burton, op. cit., 26,144, Hansen, op. cit., 303-309, J. Scott, 'The evidence of experience', Critical Inquiry, 17,4 (Summer, 1991), 773-97, here 780. S. Rudolph \& L. Rudolph, Reversing the Gaze: Amar Singh's diary, a colonial subject's narrative of 
Imperial India (New Delhi, 2000).

37 A.P.J. Abdul Kalam, India 2020: a Vision for the New Millennium (New York, 1998).

38 N. Guru, Autobiography of an Absolutist (Fernhill, 1989), 43.

39 P.S. Sundaram, Simple Simon: an autobiography (Madras, 1997), 14. N. Guru, op. cit., 6. K. Sreenivasan, Climbing the Coconut Tree: a partial autobiography (Delhi, 1980), 118. K.P.S. Menon, Many worlds: an autobiography (Calcutta, 1965), 26.

40 K.M. Panikkar, An Autobiography (Delhi, 1954), 7.

41 R.K. Laxman, 'Through the coloured glass', in G. Ramnarayan (ed.), Past Forward: six artists in search of their childhood (New Delhi, 1997), 39. Ramarau, op. cit., 8-13. See S. Sen, 'The orphaned colony: orphanage, child and authority in British India', Indian Economic Social History Review, 44 (2007), 462-488.

Nandy, op. cit.

42 M. Karlekar and R. Mukherjee (eds), Remembered Childhood (Oxford, 2010), xi. Laxman 'Through the coloured glass', op cit., 38. N. Guru, op. cit., 2. G. Ram, Rhythm in the Heavens: an autobiography (London, 1957), 4-6.

43 Menon, op. cit., 8-9. S. Rama Rau, Gifts of Passage (London, 1961), 10-12.

Sreenivasan, op. cit., 39, 70. Sundaram, op. cit., 34. Gunasekaran, op. cit., 204. 44 Laxman, 'Through the coloured glass', op. cit., 37.

45 Nataraja Guru. op. cit., 2. Sreenivasan, op. cit., 24-26. R.K. Narayan, My Days: a memoir (Oxford, 1974), 21.

46 Nandy, op. cit., 57.

47 Narayan, op. cit., 20, 51. Ramarau, op. cit., 8, 28, 33.

48 James, op. cit., 495.

49 M.C. Martin, 'The state of play: historical perspectives', International Journal of Play, 5, 3 (2016), 329-339.

$50 \mathrm{~S}$. Balagopalan, 'Constructing indigenous childhoods: colonialism, vocational education and the working child', Childhood, 9, 1 (2002), 19-34.

510 . Nieuwenhuys, Children's Lifeworlds: gender, welfare and labour in the developing world (London, 1994).

52 R. Lal, Coming of Age in Nineteenth-Century India: the girl-child and the art of 
playfulness (Cambridge, 2013), 207.

53 Viramma, J. Racine and J.-L. Racine, Viramma: life of an untouchable (London, 1997), 8.

\section{Ibid., 14.}

55 Nijalingappa, op. cit., 18-20. Mohanty, op. cit., 26. Raghumariah, op. cit., 8. C. Subramaniam, Hand of Destiny: memoirs (Bombay, 1993), 36. Sundaram, op. cit., 13, 16. Sattanathan, op. cit., 25. Gunasekaran, op. cit., 4, 20.

56 Ramarau, op. cit., 15-21. Rau, op. cit., 3-4. Menon, op. cit., 26. Chakiar, op. cit,, 77.

57 N.C. Yati, Love and Blessings (Varkala, 2000), 2. Kalam, My Journey, op. cit. Viramma, op. cit., 39. Ganesh, op cit., 275.

58 Kalam, My Journey, op cit., 52. Ram, op. cit., 8-9. Mohanty, op. cit., 5.

59 K.L. Raghuramaiah, Hurricane: autobiography of a woman (Delhi, 1993), 36-37.

Sundaram, op. cit., 17, 39-40.

60 Viramma, op. cit., 4,5,14. Nimbkar, Krishnabai Smrutika: the story of my mother as told by herself (Self-published, Pune, 1988).

61 Narayan, op. cit., 45. Laxman 'Through the coloured glass', op. cit., 38. K.R.R. Sastry, Reminiscences of a Jurist (Madras, 1963).

62 Sreenivasan, op. cit., 43.

63 S. Nijalingappa, My Life and Politics (Delhi, 2000), note 57.

64 Sreenivasan, op. cit., 16. R.K. Laxman, The Tunnel of Time (Delhi, 1971), 3. K. Das, My Story (Delhi, 1988), 6.

65 Sreenivasan, op. cit., 42. Laxman 'Through the coloured glass', op. cit., 37, 39. Kalam, My Journey, op. cit., 52. Menon, op. cit., 9. H. Raman, Daughter of the Mountains (Madras, 1993), 43-44. Narayan, op. cit., 21-24.

66 Narayan, op. cit., 58-60. Laxman, Tunnel of Time, op. cit., 2-3.

67 Report on Public Instruction in the Madras Presidency (1927-28 to 1931-32), 83.

68 M.J. Sargunam, An Autobiography (Coimbatore, 1978), 5-6, 11. Subramaniam, op. cit., 37-39. B. A.Sayeed, My Life, a Struggle (Madras, 1983). 12. Kalam, My Journey, op. cit., 35. Laxman, Tunnel of Time, op. cit., 10. Mohanty, op. cit., 30-44. C. Narasimhaiah, 'N for Nobody'. Autobiography of an English teacher (Delhi, 1991), 4-10. Narayan, op. cit., 44. N. Guru, op. cit., 2-9. Nijalingappa, op. cit., 16-21. 
Panikkar, op. cit., 3-4. Sattanathan, op. cit., 29-49.,Veeraswami, op. cit., 7. 69 Sattanathan, op. cit., 36. P.C. Alexander, Through the Corridors of Power: an insider's story (Delhi, 2004), 61. S. Muthulakshmi Reddi, Autobiography (Madras, 1964), 3. Sreenivasan, op. cit., 39. For further discussion of school buildings see Ellis, op. cit., 388.

70 A.K. Samban, Autobiography of Prof AK Samban (Madras, 1994), 19.

71 Mohanty, op. cit., 33. Sundaram, op. cit., 41-43. Laxman, Tunnel of Time, op. cit., 10-14.

72 N.G. Ranga, Fight for Freedom (Delhi, 1968) 10-11. Chakiar, op. cit., 44. P.S.

Vaidyanathan, Thoughts and Reminiscences (Chetput, 1986), 9.

73 Ellis, op. cit., 389.

74 Sreenivasan, op. cit., 49-51.

75 Narasimhaiah, op. cit., Nijalingappa, op. cit., 21. Das, op. cit., 21. Veeraswami, op. cit., 7. Chakiar, op. cit., 90. Reddi, op. cit., 3. Sargunam, op. cit., 5. Alexander, op. cit., 61-62. Subramaniam, op. cit., 38. K. Santhanam, Looking Back. Memoirs (Mumbai, 2001) 13. Narayan, op. cit., 44-45. Subramaniam, op. cit., 39. See also K. Kumar, Political Agenda of Education: a study of colonialist and nationalist ideas (New Delhi, 1991).

76 Menon, op. cit., 19, T.S. Avinashilingam, Sacred Touch: an autobiography (Bombay, 1986), 46. A.P.J. Abdul Kalam, http://www.abdulkalam.com/kalam/theme/jsp/guest/myprofile.jsp [Accessed 6/11/2015].

77 Mohanty, op. cit., 30-31. Nijalingappa, op. cit., 6. T.M. Mahadevan, A Philosopher Looks Back (Delhi, 1982) 11.

78 Laxman, Tunnel of Time, op. cit., 10-12. Narayan, op. cit., 8.

79 C. Kesavan, 'Jeevithasamaram', in Satyanarayana and Tharu, op cit., 261.

80 S. Humphries, Hooligans or Rebels? An oral history of working-class childhood and youth, 1889-1939 (Oxford, 1981). J. Scott, Weapons of the Weak (Yale, 1985). C. Ellis, op. cit., 392.

81 Das, op. cit., 18, 19, 39. Siddalingaiah, Ooru Keri: an autobiography (Bangalore, 2003). Rau, op. cit., 10. Yati, op. cit., 22. See also H. Bhabha, 'Of mimicry and man: the ambivalence of colonial discourse', October, 28 (1984), 125-33. 
82 Laxman, Tunnel of Time, op cit., 11. Narayan, op. cit., 10. Sreenivasan, op. cit., 39 Ramarau, op. cit., 10.

83 Sattanathan, op. cit, 90.

84 Sattanathan, op. cit., 40-46. Reddi, op. cit., 1. Gunasekaran, op. cit., 17-18.

85 Narayan, op. cit., 41-42, 51.

86 For more detail see N. Kumar, Lessons from Schools: the history of education in Banaras (New Delhi, 2000).

87 Balagopalan, Inhabiting Childhood, op. cit.

88 Mohanty, op. cit., 17-18. Narasimhaiah, op. cit., 5. Gunasekaran, op. cit., 23, 30, $34,84$.

89 Sattanathan, op. cit., 57-58.

90 Kalam, My Journey, op. cit., 23-26.

91 D. Sreenivas, 'Telling different tales: possible childhoods in children's literature', Childhood, 18, 3 (2011), 316-332, here 331.

92 Balagopalan, 'Constructing Indigenous Childhoods', op. cit.

93 Smrutika, op. cit., 18-20. Kalam, My Journey, op. cit., 52, Gunasekaran, op. cit., 203.

94 Raman, op. cit., 3, 9, 13, 18-19.

95 Gunasekaran, op. cit.

96 Viramma, op. cit., 9-12.

97 A. Davin, Growing up Poor: home, school and street in London 1870-1914 (London, 1996), 41.

98 N. Burra (ed.), Born Unfree: child labour, education and the state in India (Oxford, 2006).

99 Morrison, op. cit., 102, 122.

100 N. Kumar, Politics of Gender, Community and Modernity (New Delhi, 2007). C.

Ellis, 'Education for all: reassessing the historiography of education in colonial India', History Compass 6, 9 (Dec 2008), 363-375.

101 Chatterjee, op. cit. Sen, Colonial Childhoods, op. cit.

102 Rau, op. cit., 3. See also E. Newbiggin, The Hindu family and the Emergence of Modern India (Cambridge, 2012).

103 V. Tendulkar, 'View from the balcony' in Ramnarayan, op. cit. 'Semmangudi 
looks back at 90' [interview with S.S. Iyer], Frontline, 15, 22 (1998) [accessed 28/12/2018]. C.S. Lakshmi, The Singer and the Song (Dehil, 2000). M.S.

Subbalakshmi 'Songbird in springtime', in Ramnarayan, op. cit.

104 Menon, op. cit., 15. Sattanathan, op. cit., 34-38. B.K.S. Iyengar, Light on Life (London, 2005), xix. Alexander, op. cit., 60. Kalam, My Journey, op. cit., 51-55.

Kalam, Wings of Fire, op. cit., 8.

105 Raghuramaiah, op. cit., 4.

106 Sattanathan, op. cit., 42. Narayan, op. cit., 12.

107 Panikkar, op. cit., 3.

108 Subbamma, op. cit., 22. Das, op. cit. Avinashilingam, op. cit., 43. Ramarau, op. cit., 10.

109 Viramma, op. cit., 32.

110 Raghuramaiah, op. cit., 34. Sastry, op. cit., 2-3. Sreenivasan, op. cit.,58.

Panikkar, op. cit., 4, Santhanam, op. cit., 13. Avinashilingam, op. cit., 43. Laxman

'Through the coloured glass', op. cit., 40. Kalam Wings of Fire, op. cit., 8.

111 Narasimhaiah, op. cit., 4. Sundaram, op. cit,, 32-36. Sreenivasan, op. cit., 17.

Rau, op. cit., 13. Nijalingappa, op. cit., 20.

112 Sreenivasan, op. cit., 56.

113 Sreenivasan, op. cit., 54-55, Reddi, 'Interview' op. cit. Menon, op. cit., 4, 8. Ranga, op. cit., 4. Chakiar, op. cit., 59 -61. See also Kumar, Politics of Gender, op. cit.

114 Yati, op. cit., 3.

115 Raghuramaiah, op. cit., 33. Ram, op. cit., 3. Ranga, op. cit., 11-12. M. Ganesh 'My grandfather had a wish' in Satyanarayan \& Tharu, op cit., 275.

116 Sattanathan, op. cit., 79-81.

117 Sen, Colonial Childhoods, op. cit. Sen, 'Orphaned colony', op. cit.

118 A. Malagatti, 'The Bride', and N.K. Hanumanthaiah, 'Wedding lamps on Holeya

Street', (trans S.R. Ramakrishna), in Satayanarayana, op. cit., 229, 386-88.

119 Sattanathan, op. cit., 38, records his sister's experience of domestic violence; others record occasional violence.

120 Sen, Traces of Empire, op. cit., 78.

121 Viramma, op. cit., 9. 
122 Balagopalan, op. cit., 45. Malagatti, op cit., 229.

123 Balagopalan, op. cit., 39.

124 Sreenivasan, op. cit., 18, 22.

125 Subbamma, op. cit., 10-14. Raman, op. cit., 63. Raghuramaiah, op. cit., Das, op. cit. Viramma, op. cit., 32. Smrutika, op. cit., 20.

126 Viramma, op. cit., 32. Sreenivasan, op.cit., 31.

127 Reddi, op. cit., 5-7. Rau, op. cit.

128 B. Bagchi, 'Two lives: voices, resources, and networks in the history of female education', Women's History Review, 19, 1 (2010), 51-69.

129 Karlekar \& Mukherjee, op. cit., 134.

130 Raman, op. cit., 35. Sen, Traces of Empire, op. cit., 80.

131 K. Kumar, 'Childhood in a globalising world', Economic and Political Weekly, (2006), 4030-4034.

132 Nandy, op. cit., 57.

133 R. Bernstein, Racial Innocence: performing American childhood (New York, 2011).

134 Sen, Colonial Childhoods, op. cit. Pomfret op. cit.

135 Das, op. cit., 13. N. Guru, op. cit., 4.

136 Rau, op. cit., 6-12.

137 Alexander, op. cit. See also N. Etherington, Missions and Empire (Oxford, 2005).

138 Ramarau, op.cit., 9. Mahedevan, op. cit., 13.

139 Das, op. cit., 13. Mohanty, op.cit., 32. K. Shridharani, My India, My West (London, 1942).

140 Rau, op. cit., 13.

141 Mohanty, op. cit., 50-52, Nair, op.cit., 186. For secondary literature see $\mathrm{H}$.

Bellenoit, Missionary Education and Empire in Late Colonial India, 1860-1920 (London, 2007). N. Chandra, 'The pdagogic imperative of travel writing in the Hindi world: children's periodicals (1920-1950)', South Asia: Journal of South Asian Studies, 30, 2 (2007), 293-325. S. Sen, 'Anarchies of youth: the Oaten affair and colonial Bengal', Studies in History 23, 2 (2007), 205-229.

142 Mohanty, op.cit., 50.

143 Ramarau, op.cit., 33. 
144 Kalam, http://www.abdulkalam.com/kalam/theme/jsp/guest/myprofile.jsp [Accessed 6/11/2015].

145 Kalam, Wings of Fire, op. cit. 8-9.

146 Kalam, My Journey, op. cit., 33- 39.

147 Karlekar and Mukerherjee, op. cit. Morrison, op. cit., 102.

148 Alexander, op. cit., 51-55.

149 Balakrishnan, op. cit.

150 Gayathri, op. cit. S. Raman, Getting Girls to School (Chennai, 1996). S.

Seth, Subject Lessons: the western education of colonial India (Durham, 2007).

151 K. Chandy, Quest of Community and Dynamic Non-Violence (Delhi, 1993).

Raman, op. cit., 37-38.

152 Panikkar, op. cit., 3. Santhanam, op. cit., 13. Subramaniam, op. cit., 38. Kalam, My Journey, op. cit., 35, M. Arjunamani and M. Dhanasekar, Tale of a Tamil Widow (Rockhampton, 2001), 7. Das, op. cit., 13. Mohanty, op. cit., 32. N. Guru, op. cit., 2. Raghuramaiah, op. cit., 25. Subbamma, op. cit., 10.

153 Reddi, op. cit., 5-7.

154 Ravikumar, op. cit. S.M. Mohamed Koya, 'Muslim politics in Madras in 1930s and 1940s: the rise of Muslim League and related developments', Proceedings of the Indian History Congress, 63 (2002), 757-761.

155 Vaidyanathan, op. cit., 16.

156 Chandy, op. cit., 10. Yati, op. cit., 28. Subbamma, op. cit., 20. Nataraja Guru, op. cit., 9.

157 Report on Public Instruction, op. cit.

158 Siddalingaiah, op. cit., 17. Das, op. cit., 43.

159 Gunasakeran, op. cit., 5.

160 Ibid, 9, 18.

161 Sattanathan, op. cit., 32.

162 Ibid, 52.

163 L. Elayaperumal, 'The flames of summer' in Ravikumar, op. cit., 184.

164 Veeraswami, op. cit., 4.

165 Das, op. cit., 17. Menon, op. cit., 23.

166 Subramaniam, op. cit, 35. 
167 Sreenivasan, op. cit., 18.

168 Chakiar, op. cit., 115, 146.

169 Elayaperumal, op. cit., 185.

170 Ravikumar, op. cit. R.Kumar, Dalit Personal Narratives: reading caste, nation and identity (Hyderabad, 2010).

171 K. Pokkudan 'My Life, Ende Jeevitham', in Dasan et al (eds) op. cit., 185.

172 Gunasekaran, op. cit., 21, 25, 43, 51, 81.

173 T. Ramaiah ' Manegara: excerpts' (trans Maitreyi Karnoor), in Satyanarayana and Tharu, op.cit., 190.

174 Pokkudan, op. cit., 186-7.

175 R. Srinivasan, 'A brief history of my life' in Ravikumar et al., op. cit., 177.

$176 \mathrm{H}$. Israel, 'Contemporary Tamil dalit literatures in translation', unpublished seminar paper, 24 April 2016, University of Edinburgh. Nagaraj, op. cit., 193.

Satyanaryana and Tharu, op cit., 37.

177 Chakiar, op. cit., 27.

178 See C. Walikar 'On a raft made of entrails' (trans. S. Jayasrinivasa Rao), in Satyanarayana and Tharu, op cit., 83-93.

179 Anderson, op. cit., 19. 